\title{
Web-based Inventory Application Development for PT. Palugada Indonesia
}

\author{
Justin A. Haratua ${ }^{1}$, Andree E. Widjaja ${ }^{2}$, Kusno Prasetya ${ }^{3}$, Hery ${ }^{4}$ \\ 1,2,3,4 Information System, Universitas Pelita Harapan, Tangerang, Indonesia \\ ${ }^{1}$ justinansako@yahoo.com, ${ }^{2}$ andree.widjaja@uph.edu, ${ }^{3}$ kusno.prasetya@uph.edu, ${ }^{4}$ hery.fik@uph.edu
}

Accepted on May 23, 2021

Approved on June 15, 2021

\begin{abstract}
PT. Palugada Indonesia still records their transactions and inventory of goods in traditional ways, which could result in some errors caused primarily by human interventions. The aim of this research is to assist PT. Palugada Indonesia to control their inventory through an information system. Specifically, a webbased application that can process product data, supplier data, customer data, user data and transaction data was purposefully developed in this study. In addition, the developed application has notification and sales forecast features. These features are expected to further assist PT. Palugada Indonesia to control their inventory optimally. Moreover, the application also has some other useful features, for instance in displaying more informative data, by bringing up sales forecasts and notifications. The developed application was modeled using UML diagram 2.0 and developed using HTML, PHP, and MySQL database.
\end{abstract}

Index Terms-inventory; PT. Palugada Indonesia; sales forecast; web-based application

\section{INTRODUCTION}

\section{A. Background and Purpose}

In the era of globalization, Information Technology (IT) has become an essential factor that companies use to make decision and distribute information between stakeholders. One of many applications of IT is web-based Information System for inventory management. Information System is a group of components that work together to collect, manage, calculate, store and distribute information to support decision making, coordination, control, problem analysis and visualization in an organization [1]. General understanding of inventory is goods or materials that are owned by a business for a purpose certain, such as resale or repair [2]. Meanwhile, the website can be interpreted as a facility channel that contains a page set that is display data information [1].

The web-based inventory information system can facilitate companies in processing data on incoming goods, outgoing goods and provide the information for availability of goods, as the system can be accessed directly anytime and anywhere. This is different with the conventional inventory system that processes data manually. Manually processed data can result in data errors and inaccuracies due to human mistakes. Other than that the length of the information sharing process can lead to some calculation errors. PT. Palugada Indonesia which is engaged in redox water distribution, annually handles deals for up to four tons of pure redox water which is the largest number of transactions in the islands of Java and Sumatra. However, they still record their transactions and inventory of goods in conventional ways, which could result to some problems mentioned before. Some major identified problems are the followings:

- The process of recording incoming goods, goods that are exit and the availability of goods were done manually; hence it took longer time to record and count.

- Manual calculations lead to difficulties in searching information on the availability of goods accurately.

- Lack of company awareness when availability of goods is running low, resulting in serious problems in controlling the availability of goods.

- Manual recording of data makes it difficult for companies to get hold of information quickly and accurately.

Hence, the purpose of this current study is therefore to solve the aforementioned problems by developing a web-based inventory application for PT. Palugada Indonesia, which has the following main functions:

- Calculate incoming goods, outgoing goods and available goods in easier, more detailed and accurate manners.

- Assist companies to maintain the availability of goods with the notification feature.

- Quickly obtain information of transaction and inventory to be used in decision making.

The functions included in the developed webbased inventory application aforementioned are significant and important for PT. Palugada Indonesia to overcome its problems. However, it is important to 
note that the developed application has some limitations, they are:

- The developed application is only limited to processing data, the entry and exit of goods and the availability of goods. In addition, it can be used as a means to display existing data through the website.

- The notification feature is limited only to assist the provision of goods.

- The application is particularly designed and intended for the operational field of inventory, operational managers and directors at PT. Palugada Indonesia.

\section{B. Literature Review}

Inventory can be defined as goods that are used to facilitate production or meet consumer demand [3]. Other experts conceptualize inventory as companyowned goods that are stored with the aim of being sold for a certain period, goods that are still in the production stage, or raw materials to be used for a production process [4]. Inventory is an investment decision, so care is needed in controlling the availability of goods [5]. So, errors in controlling the availability of goods can harm the company. Inventory has a main function in ensuring the smoothness of the mechanism for fulfilling consumer demand so that the managed system achieves optimal results [6].

The System Development Life Cycle (SDLC) is a process for understanding how information systems can support business needs through designing a system [7]. SDLC is a gradual improvement process so that each stage can improve and elaborate on the work that has been done previously. SDLC consists of four basic stages, namely planning (planning), analysis (analysis), design (design) and implementation (implementation).

Rapid Application Development (RAD) has been developed since the early 1990s. RAD-based methodologies make several adjustments to the stages of the System Development Life Cycle (SDLC) aimed at providing faster results to users, making it easier for users to understand and analyze the system [7]. The RAD methodology is divided into three methods, namely phased development, prototyping, and throwaway prototyping. The method used in this current study is the prototyping method. The main purpose of this method is to develop the model to be a final working system. Unlike SDLC traditional method, the prototyping method has a faster development phase and a lower cost [7].

Unified Modeling Language (UML) is the result of standardized diagram making that has been accepted by the Object Management Group (OMG). It aims to provide a general term for object-oriented development [7]. UML was created by having four main functions [8], namely: Visualizing, specifying, constructing, and documenting.

Relational Database Management System (RDBMS) is a system that uses the relational data model to manage data sets. Meanwhile, the Database Management System (DBMS) itself is a set of interrelated data, including programs and procedures for accessing and managing data [9]. Database is a collection of data that is stored and used by certain application systems. Databases are useful for combining and controlling data centrally so that it can reduce the repetitive same data (data redundancy), which can make data use easier. Meanwhile, structured Query Language (SQL) is the language used to access databases and includes two main components, namely Data Definition Language (DDL).

Sales Forecasting is the process of forecasting future business sales [10]. The sales forecast period can be in per month, per quarter, per half year to yearly. With the idea of future sales, this will make it easier for businesses to manage the availability of goods, cash flow and future growth plans. The purpose of forecasting sales is to provide information that can be used in making business decisions [10]. There are a variety of sales forecasting methods, such as executive jury opinions, labor force opinions, marketing results testing, consumer purchase plans, market factor analysis, expert opinion, econometric model building, statistical methods and past sales (historic method). The past sales method (historical method) or the past sales method is the method that will be used for this study.

Related Works. Table I summarizes the relevant prior studies pertaining to the development of inventory application. As seen in table 1 below, it can be concluded that the majority of prior studies merely focus on the main functions of inventory system. There are two important functions that were missing from the extant literature, such as notification features and sales forecasting. These two features were included in our developed application, and therefore, becoming the main contribution or novelty of this current study.

TABLE I. RELATED WORKS SUMMARY

\begin{tabular}{|c|c|c|c|}
\hline \multirow{2}{*}{ Ref. } & \multicolumn{3}{|c|}{ Remarks } \\
\hline & Title & Type & Summary \\
\hline [11] & $\begin{array}{l}\text { Web-based } \\
\text { inventory } \\
\text { application using } \\
\text { PHP and MySQL } \\
\text { programming } \\
\text { language (case } \\
\text { study of } \\
\text { pekanbaru hang } \\
\text { tuah stikes) }\end{array}$ & Journal & $\begin{array}{l}\text { The development of } \\
\text { inventory } \\
\text { application for data } \\
\text { analysis and } \\
\text { reporting. }\end{array}$ \\
\hline [12] & $\begin{array}{l}\text { Web-based } \\
\text { inventory } \\
\text { application at PT. } \\
\text { Telkomsel NS }\end{array}$ & Journal & $\begin{array}{l}\text { The development of } \\
\text { application to } \\
\text { automatically } \\
\text { generate serial }\end{array}$ \\
\hline
\end{tabular}


ISSN 2355-0082

\begin{tabular}{|c|c|c|c|}
\hline \multirow{2}{*}{ Ref. } & \multicolumn{3}{|c|}{ Remarks } \\
\hline & Title & Type & Summary \\
\hline & Tasikmalaya & & $\begin{array}{l}\text { number, and for } \\
\text { reporting }\end{array}$ \\
\hline [13] & $\begin{array}{l}\text { Analysis and } \\
\text { implementation of } \\
\text { inventory items } \\
\text { application web- } \\
\text { based using } \\
\text { Codeigniter } \\
\text { framework }\end{array}$ & Journal & $\begin{array}{l}\text { The development of } \\
\text { web-based } \\
\text { inventory system to } \\
\text { assist the company } \\
\text { in managing } \\
\text { inventory related } \\
\text { data }\end{array}$ \\
\hline [14] & $\begin{array}{l}\text { Analysis and } \\
\text { design of web- } \\
\text { based ship spare- } \\
\text { parts inventory } \\
\text { information } \\
\text { system: Case } \\
\text { study Asia Group } \\
\text { Pangkalpinang }\end{array}$ & Journal & $\begin{array}{l}\text { Designing web- } \\
\text { based inventory } \\
\text { system to improve } \\
\text { the spare-parts } \\
\text { inventory data } \\
\text { management }\end{array}$ \\
\hline$[15]$ & $\begin{array}{l}\text { Design of goods } \\
\text { inventory } \\
\text { application at PT. } \\
\text { Kartika Graha } \\
\text { Indonesia - using } \\
\text { Java Netbeans }\end{array}$ & Journal & $\begin{array}{l}\text { The development of } \\
\text { inventory } \\
\text { application for } \\
\text { better inventory } \\
\text { management and } \\
\text { goods control }\end{array}$ \\
\hline [16] & $\begin{array}{l}\text { The } \\
\text { implementation of } \\
\text { inventory-based } \\
\text { information } \\
\text { system (Case } \\
\text { study of CV. Sinar } \\
\text { Abadi Cemerlang) }\end{array}$ & Journal & $\begin{array}{l}\text { Designing inventory } \\
\text { system which has } \\
\text { several functions, } \\
\text { such as data and } \\
\text { transaction } \\
\text { reporting }\end{array}$ \\
\hline
\end{tabular}

- System evaluation. The system was carefully evaluated both by the developers (researcher) and by the users (staff, managers, admin, and also the owner of PT. Palugada Indonesia). A final interview with the users was carried out to ensure that the application was developed according to the users' requirements.

- System implementation. The system was implemented using local host.

\section{RESULTS AND ANALYSIS}

\section{A. Use Case Diagram}

Use Case diagrams (as seen in Fig. 1) describe the functions that can be performed in the system. The users are divided into several actors as follows:

- Staff are actors who describe all employees of PT. Palugada Indonesia that has been registered in the system. Staff are actors who have the lowest access rights in the system.

- Managers are actors who have higher access rights and also have staff features and can access validation features, notifications, dashboards, product settings and supplier settings.

\section{METHOD}

In conducting this study, there are two stages of method that was used, namely: First stage is about Data Collection Methods, which consist of literature review, field study, observation, interview, and survey. The second stage is the system development, which used RAD, specifically Prototype development method [7], which included several phases, namely:

- Requirement gatherings. In this step, the users' requirements were carefully captured (through field study, observation, interview, and survey). All of the required functions were recorded and modeled using three UML diagrams, they are: use case diagram, class diagram, and table relationships diagram.

- Prototyping development. The prototype of the application was circumspectly developed, following the users' requirements.

- Prototyping evaluation. The developed prototype was then evaluated by the users (in this case the staff and manager). Afterwards, based on their inputs, the prototype was further improved.

- System coding. The coding (programming) process of the application was performed.

- System testing. In this step, the black box testing method was incorporated to test the developed application.

- Admin is an actor who can also use all the features used by the manager and added features of customer settings and user settings at PT. Palugada Indonesia.

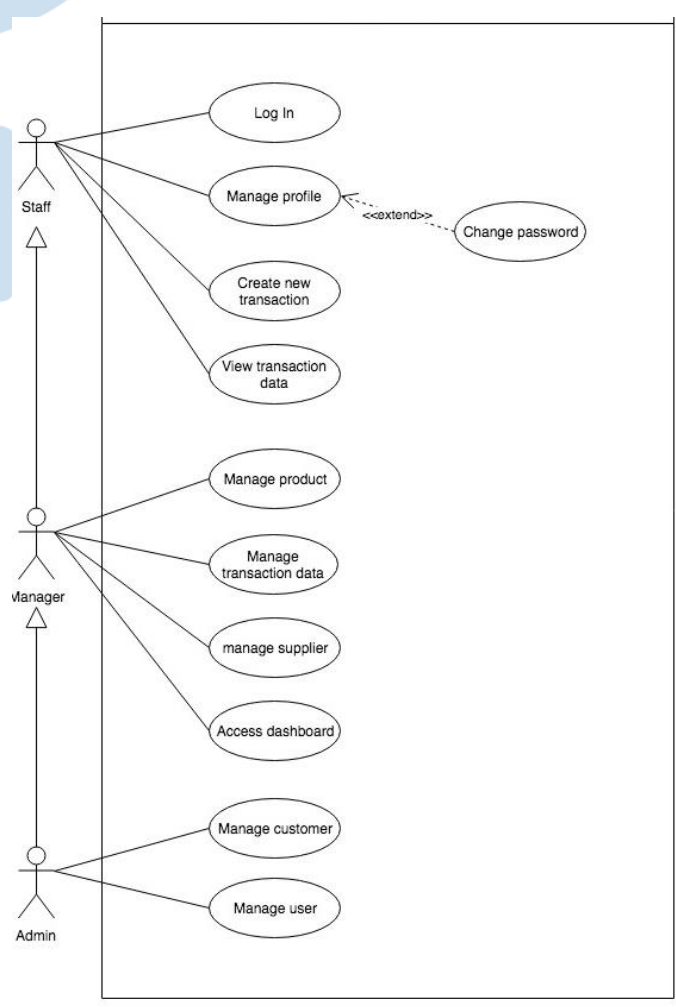

Fig. 1. Use Case diagram inventory application PT. Palugada Indonesia 


\section{B. Class Diagram and Table Relationship Diagram}

Structural modeling aims to describe the structure of the proposed system. The structural modelings used are class diagrams and table relationship diagrams. Both diagrams can be seen in the appendix 1 and appendix 2 .

\section{Business Process}

Inventory application of PT. Palugada Indonesia has several business-process related features including:

- Notification feature applies to items that have a playing category on the system. A notification will be raised when inventory reaches $25 \%$ and less than $25 \%$. The product's color will also change to red on notifications and on the dashboard.

- Customer points, customers who make a purchase will get 1 (one) point for each purchase with a total price of 10,000 and multiples apply. Points can be exchanged for products with promotion status on the system. 1.000 points can be exchanged for 1 (one) promo product. The amount of point exchange that can be done in one transaction is 10.000 points.

\section{User Interface Design}

Inventory application of PT. Palugada Indonesia has three different access levels, and each of them has a different interface design according to the functions that have been provided. Inventory information system of PT. Palugada Indonesia can only be used if the user logs in first. The log in page consists of the username and password fields which will be filled in by the user. After filling in the two fields the user presses the $\log$ in button to enter the system. If the username and password are not registered in the database, the system will generate an error message. The log-in page interface can be seen in Fig. 2 below.

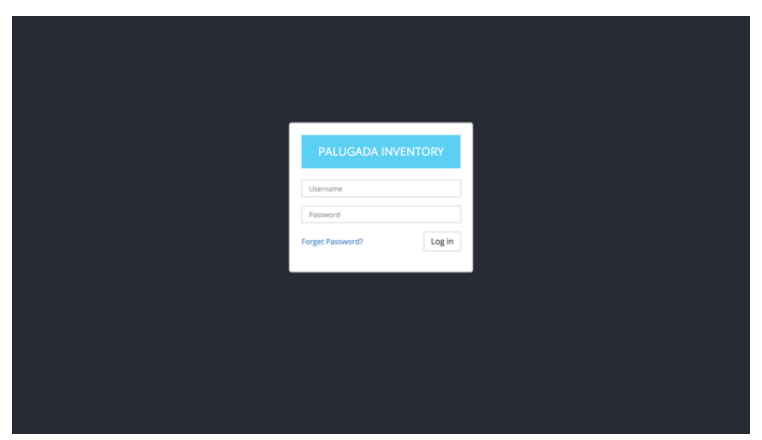

Fig. 2. Login page

Dashboard page (as shown in Fig. 3) can only be accessed by the access manager and admin levels. This page shows the name, a brief description of the product and product supplies. Products with an inventory that has reached $25 \%$ or less than $25 \%$ will turn red.

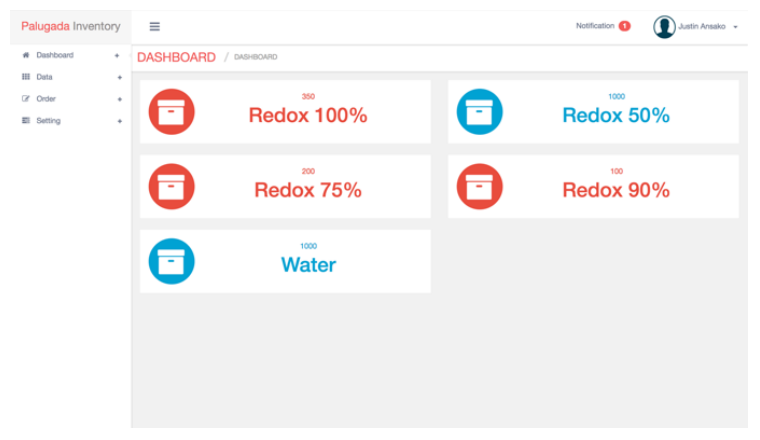

Fig. 3. Dashboard page

Products can be selected to view sales charts and forecasting for sales of these products (as seen in Fig. 4). Meanwhile, Fig. 5 shows notification features that can be used by the access manager and admin levels. Notifications are only for products in the main category which can be set on the product settings page. The notification badge will appear when the inventory reaches $25 \%$ or less than $25 \%$, and will disappear when the product has been added again.

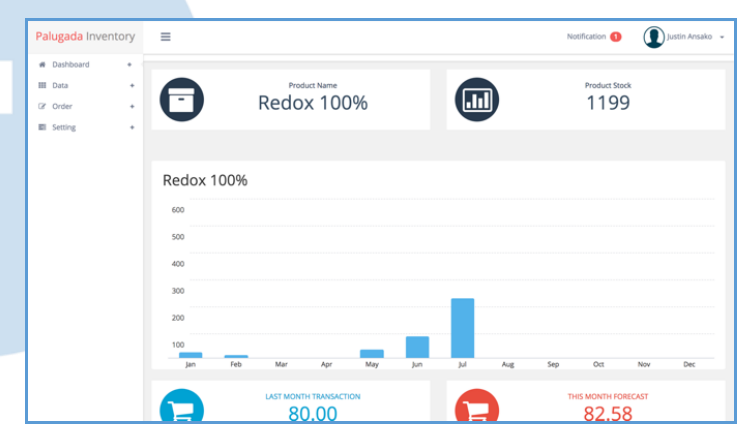

Fig. 4. Dashboard product page

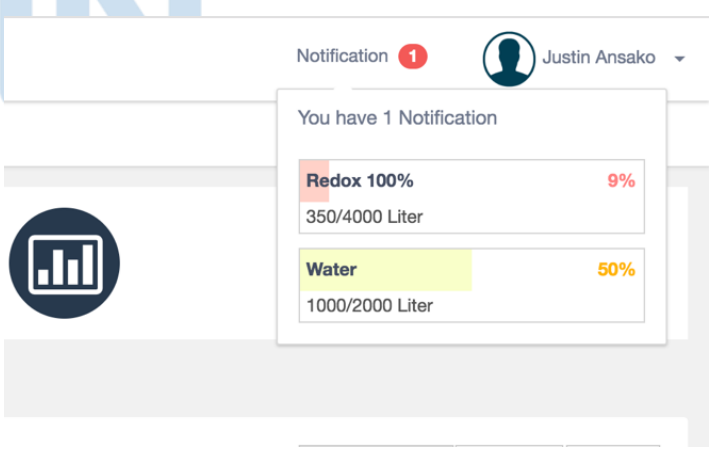

Fig. 5. Notification feature

Fig. 6 shows the stock out data page. This page displays a table of stock outs and the number of transactions for the day. In this table, there are customer names, delivery types, date of exit, employees who enter data, information, invoice button, validation button (only owned by the access manager and admin levels), and a delete button. 


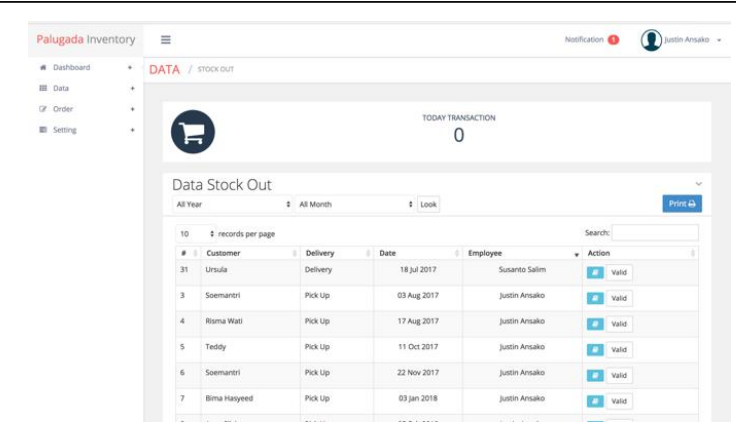

Fig. 6. Stockout data page

Pressing the invoice button will display the invoice page (as shown in Fig. 7). Meanwhile, Fig. 8 shows the invoice of a transaction, the system shows a preview of the page to be printed.

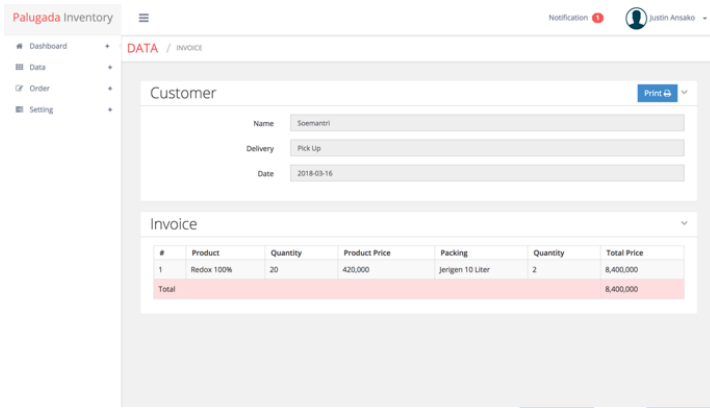

Fig. 7. Invoice data page

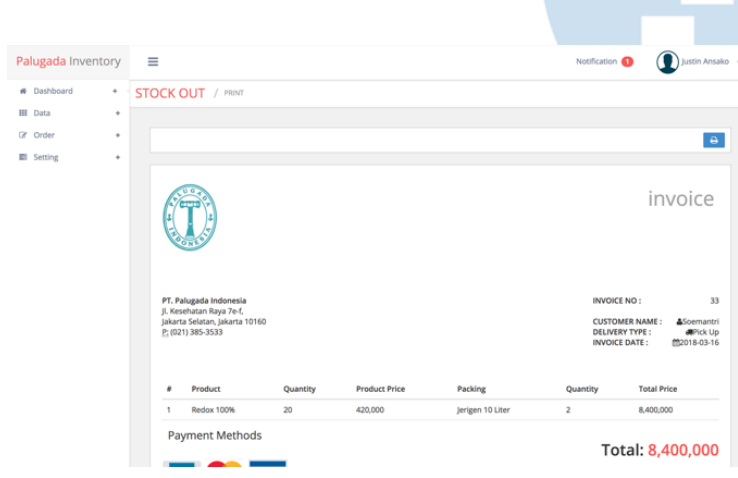

Fig. 8. Printing preview page

\section{DISCUSSION}

\section{A. Testing}

Testing the inventory application of PT. Palugada Indonesia was carried out using the black box testing method which aimed to test the smoothness of the functions that exist in the system. Black box testing tested whether the output generated by the system was as expected. In this study, all functions in the application were tested in accordance to the black box testing method, in which the users (testers) would test the function, and ensure whether all tested functions works as expected (Passed) or not (Failed). In general, the testing was conducted successfully. Some samples (in form of the testing tables) from the test results are provided in the appendix 3.

\section{B. Conclusions}

A web-based inventory application for PT. Palugada Indonesia has successfully been developed. The application can assist the process of recording and viewing transaction data, inventory, customers, users and suppliers. This application can also help the managers of PT. Palugada Indonesia to get notifications when the availability of goods is low. This system can fulfill the needs of the companies, such as:

- PT. Palugada Indonesia has a digital means to record and view every transaction that occurs.

- PT. Palugada Indonesia has a means to store and display customer data, supplier data, and user data.

- There is a means to display the condition of inventory in an informative manner at PT. Palugada Indonesia.

- Synchronized data so that all employees have the same data, thereby minimizing data errors or information that an employee has.

- The notification feature in the system makes it easy for PT. Palugada Indonesia when the inventory was running low.

- With the sales forecast feature, thus helping companies to estimate the availability of goods.

- A feature to validate transaction data helps PT. Palugada Indonesia, when a transaction is already valid, it cannot be changed again.

- All of the features above can be used by the decision maker to decide what to stock in the future.

\section{Suggestions}

Some useful suggestions that can be proposed to develop a web-based inventory information system at PT. Palugada Indonesia are the followings:

- Added accounting features, so that companies can immediately get financial reports.

- Adding e-commerce features, so that customers can directly make purchases online via the web.

- Adding a tracking feature on delivery of goods, as well as detailing the details of delivery of goods. 
APPENDIX

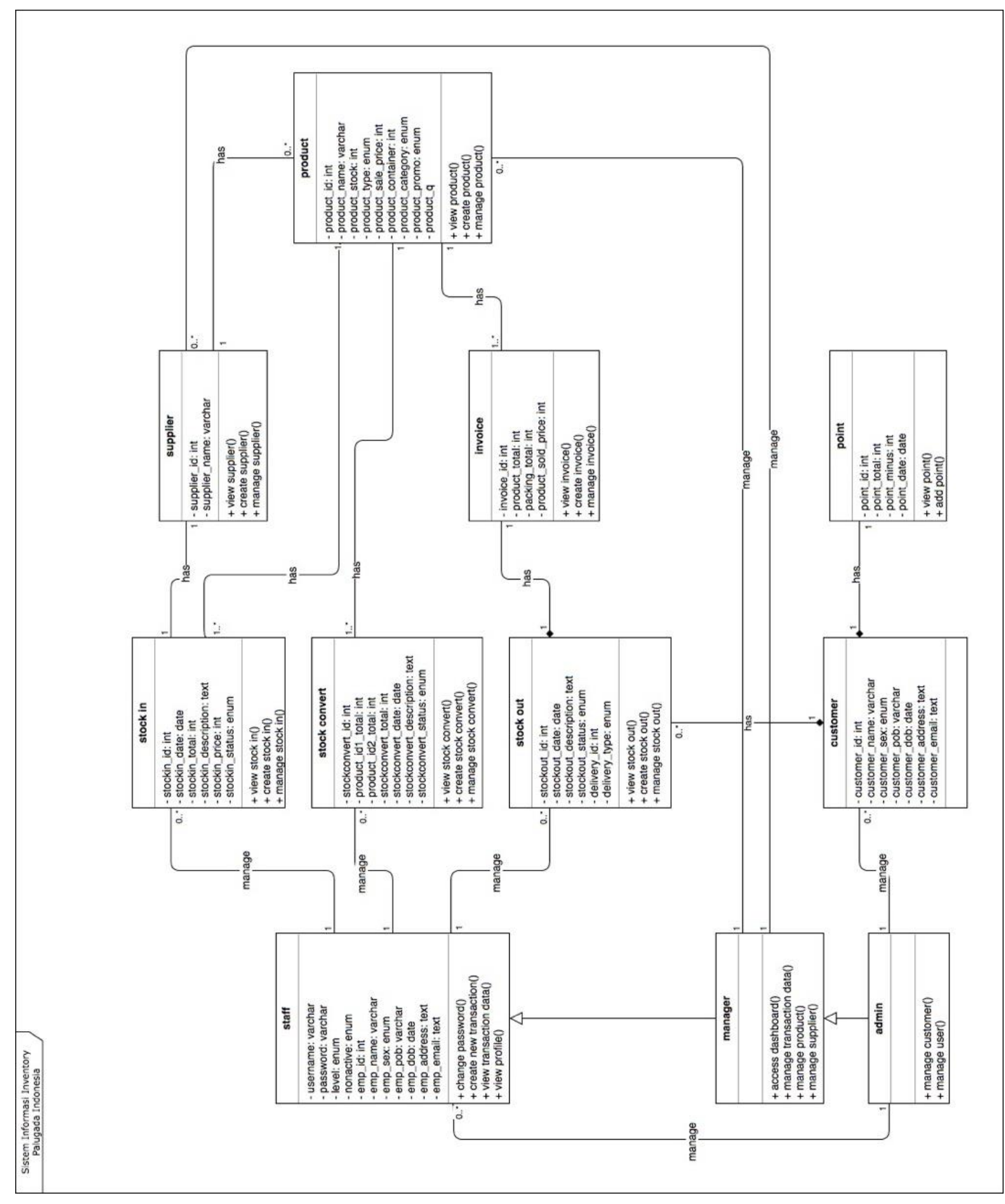




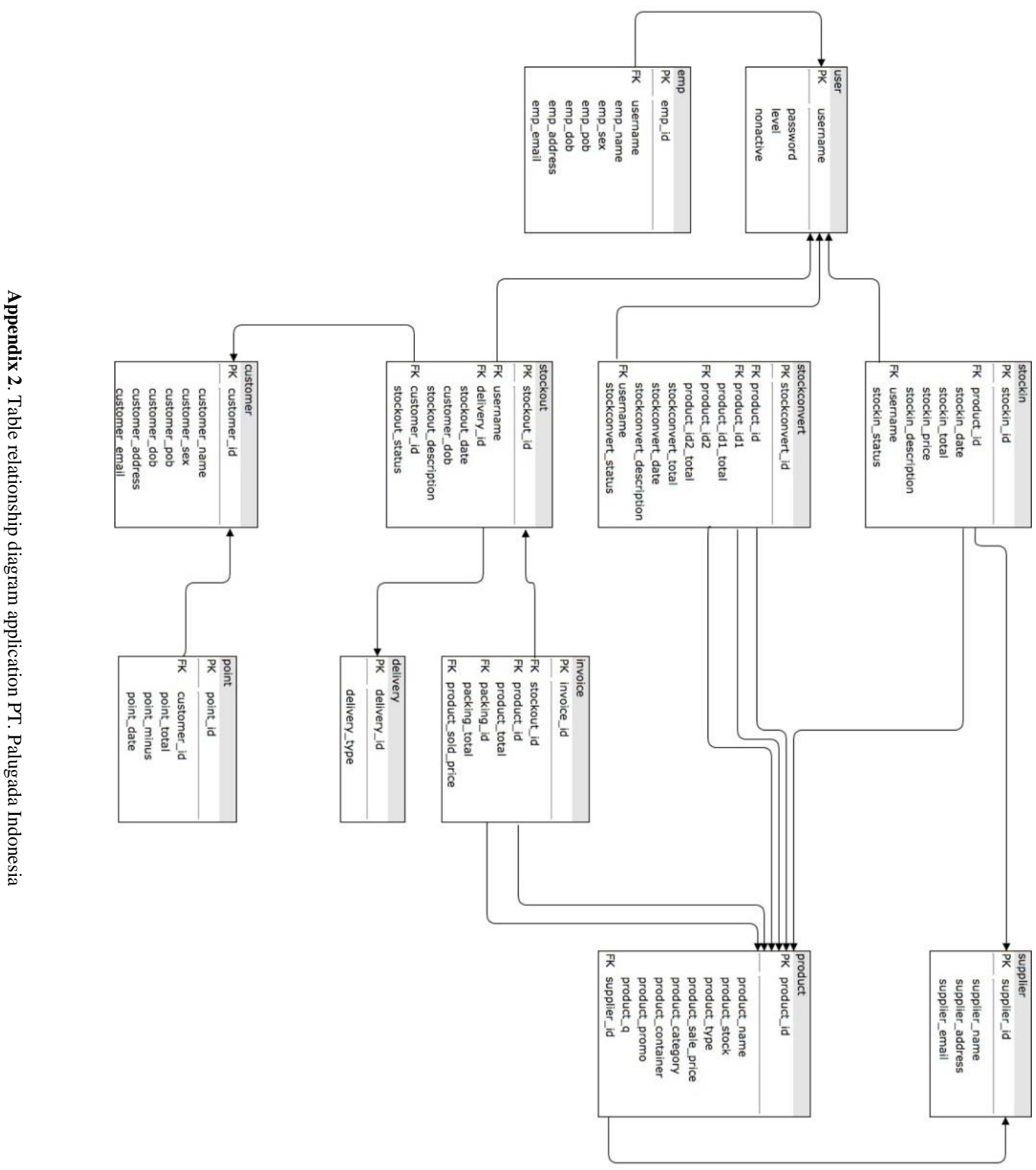




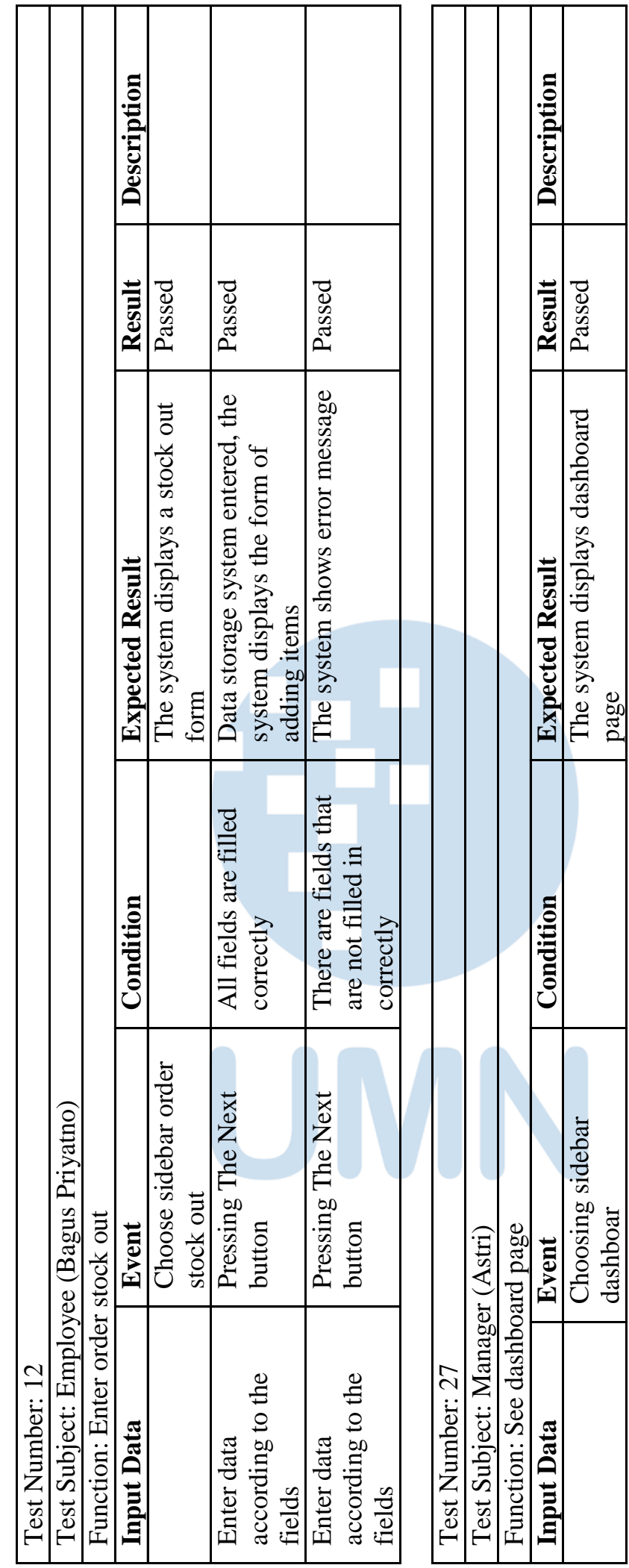

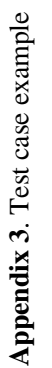




\section{REFERENCES}

[1] K. C. Laudon and J. P. Laudon, Management Information Systems: Managing The Digital Firm, 16th ed. New Jersey: Pearson, 2020.

[2] S. Gupta and M. Starr, Production and Operations Management Systems, 1st ed. Florida: CRC Press, 2014.

[3] H. A. Taha, Operations Research: An Introduction, $10^{\text {th }}$ ed. New Jersey: Pearson, 2017.

[4] R. Vikaliana, Y. Sofian, N. Solihati, D. B. Adji, and S. S. Maulia, Manajemen Persediaan, Bandung: Media Sains Indonesia, 2020.

[5] J. Heizer, B. Render, C. Munson, Operations Management:Sustainability and Supply Chain management, $13^{\text {th }}$ ed. New Jersey: Pearson, 2020

[6] A. Eunike, N. W. Setyanto, R. Yuniarti, I. Hamdala, R. P. Kukodono, and A. A. Fanani, Perencanaan Produksi dan Pengendalian Persediaan. Malang: UB Press, 2018

[7] A. Dennis, B. H. Wixom, and D. Tegarden, Systems Analysis and Design: An Object-Oriented Approach with UML, 5 th ed. New Jersey: John Wiley \& Sons, 2015.

[8] G. Swain, Object-Oriented Analysis And Design Through Unified Modeling Language. New Delhi: Laxmi Publications Pvt Ltd, 2017.

[9] R. Elmasri and S. B. Navathe, Fundamentals of Database Systems, 7th ed. New Jersey: Pearson, 2016.

[10] P. Kotler and K. L. Keller, Marketing Management. New Jersey: Pearson, 2016.

[11] U. Rahmalisa, "Web-based inventory application using PHP and MySQL programming language (case study of pekanbaru hang tuah stikes - Aplikasi inventory berbasis web menggunakan bahasa pemrograman PHP dan MySQL (studi kasus stikes hang tuah pekanbaru)," Jurnal Ilmu Komputer, Vol. 7, No. 2, pp. 51-57, 2018.

[12] G. P. Khasani and D. J. Surjawan, "Web-based inventory application at PT. Telkomsel NS Tasikmalaya - Aplikasi inventory berbasis web pada PT. Telkomsel NS Tasikmalaya," Jurnal Teknik Informatika dan Sistem Informasi, Vol. 2, No. 3, pp. 319-330, 2016.

[13] A. Rahman, "Analysis and implementation of inventory items application web-based using Codeigniter framework Analisis dan implementasi sistem aplikasi inventory items berbasis web menggunakan framework codeigniter," AI Ulum Sains dan Teknologi, Vol. 2, No. 1, pp. 35-38, 2016.

[14] Hengki and S. Suprawiro, "Analysis and design of web-based ship spare-parts inventory information system: Case study asia group pangkalpinang - Analisis dan perancangan sistem informasi inventory sparepart kapal berbasis web: Studi kasus asia group pangkalpinang," Jurnal SISFOKOM, Vol. 6, No. 2, pp. 121-129, 2017.

[15] A. D. Pratiwi, "Design of goods inventory application at PT. Kartika Graha Indonesia using Java Netbeans - Perancangan aplikasi inventory barang pada PT. Kartika Graha Indonesia berbasis Java Netbeans," JRAMI Jurnal Riset dan Aplikasi Mahasiswa Informatika, Vol. 1, No. 3, pp. 355-360, 2020.

[16] A. Fauzi, N. Indriyani, and A. B. H. Yanto, "The implementation of inventory-based information system (case study of CV. Sinar Abadi Cemerlang) - Implementasi sistem nformasi inventory berbasis web (studi kasus: CV. Sinar Abadi Cemerlang)," Jurnal Teknologi dan Open Source, Vol 3, No. 2, pp. 144-157, 2020. 